\title{
CCCLVI. SURATTE.
}

\section{Novembur $1674 .^{1}$ )}

Van welke beteekenis deze „directie" in die dagen was, blijkt uit de ,heerlyk suyvere overwinste boven alle ongelden” van $f 855285,18,8$, volgens de boeken gesloten 14 Juni 1674 (Dagh-Register 1674, bldz. 320). Toch waren, „de geweldenaeryen des gouverneurs, etc. soo groot, dat men daer langer niet conde negotieren ende daeromme geresolueert had eens een inzicht van de gelegentheyd der stad Cambaja ${ }^{2}$ ) te doen nemen", zooals de directeur Volger den 8 October aan G. G. en R. berichtte (Dagh-Register 1674, bldz. .349). Spoedig daarop veranderde de toestand: met de onverwachte komst van een tweetal schepen der Compagnie waren „de onbeschofte Moorse gewelden des gouverneurs, etc. heel gecesseert en zy daardoor in sulken na bedenken gebragt, dat alle pretentien en inciviliteyten tegens de Comp ${ }^{e}$ meest wederomme ${ }^{3}$ ) waren bygeleyt en satisfactie van gedaan" (Missives van Volger van 17 December 1674. Vgl. Dagh-Register 1675; bldz. 64, 84 , v.).

Handschrift van den gouverneur Geasdischan ${ }^{4}$ ) op den $27^{\text {en }} 9^{\text {ber }}$ 1674 ten faveure van de Nederlandsche Comp ${ }^{1 e}$ verleent aan den Ed. heer Willem Volger, ${ }^{5}$ ) raad extraordinaris van India, commissaris en directeur tot Suratte, ten selven dage overgelevert.

Luijdende getranslateert in onse Nederduytse tale aldus :

alle hooge en lage officiers van 't Suratse tholhuys, zoo tegenwoordige als toekomende, sij kond en kennelijck dat alle negotianten, die van de Nederlanderen het coper handelen, d'ordinaire en voor desen in gebruijk geweest zynde Comp ${ }^{\text {ies }}$ geregtigheyt van de munt sullen werden vrijgeschonken, buyten dat so sal men aan sodanige negotianten tuytvoeren van $\mathrm{d}^{\circ}$ mineraal om gene oorsaken ook mogen verhinderen, maar $t$ selve sal haar alles, gelyck gesegt, sonder de geregtigheyd aan de munt te voldoen, vrij en liber vergunt werden.

Soo mede sullen sij, Nederlanders, soo vele contanten en goederen naar Bengale en andre gewesten ivan hier vervoeren als zullen begeren, sonder dat haar dat sal mogen werden belet.

Desgelijx sullen haar ook gene maintementos ${ }^{6}$ ) ten behoeve harer

1) Uit het Contractboek. Ook in Batavia.

${ }^{2}$ ) Cambay op $22^{\circ} 18^{\prime} \mathrm{N}$. B. en $72^{\circ} 40^{\prime}$ O. L. (Vgl. Corp. Dipl., I, bldz. $269,278,331)$.

3) Vgl. hiervóór, bldz. 218, 223, v.v.

4) De gouverneur bestuurde de stad namens den Groot-Mogol Aurangzib. (Vgl. Hunter, Gazetteer XXIII, p. 155. - Zie ook hiervóór, bldz: 215).

5). Hij was 1673 opgevolgd aan Andries Bogaert. (Dagh-Register 1672, bldz. 216, 234, 1673, bldz. 208).

(i) Levensmiddelen. 
schepen en sooveel met deselve van hier soude willen vervoeren, mogen werden geweijgert.

Dat sy hare coopmanschappen en goederen, die telkens aanbrengen, ook sullen mogen overdoen aan wien begeren, sonder dat men haar daarmee de minste nadeel sal mogen toebrengen.

Haar aancomende geladene vaartuygen sal men ten eersten ontlossen, de goederen in haar packhuijs opslaan ende deselve van daar sonder versuijm (en wanneer die in hun logie begeren) aan haar ook moeten laten volgen.

In alle wijdere saken, die sij mogen versoeken ende benodigt sijn, sal men haar, sonder van hun eenige giften of gaven op 't een of 't ander pretext af te vorderen, steets behulpig zijn en haar redelijke begeerten naarkomen.

Dit vorenstaande sal dan van een yder, die mogte aangaan, promtelijk geobserveert en naargekomen moeten werden. Boven dit geschrift stond den voorm ${ }^{\text {te }}$ gouverneur Geasdischan sijn siap met inkt gedruckt. Onder stond: gecollationeerd, accordeert met syn minute, Suratte ady 24 April 1675 ; was getekent $G^{s}$ Hooft. $D^{\text {ie }}$ clercq. ${ }^{1}$ )

\section{KUST VAN KOROMANDEL-GOLKONDA.}

\section{November-December $1674 .^{2}$ )}

„In het Jaar 1674 was ' $r$ weder oneenigheid over de drie duyzend oude Pagoden, ${ }^{3}$ ) of de vyf-en-twintig-duyzend guldens, en toen geliefde het den Konink een nieuw scherp bevel uyt te laten gaan" (Havart, t.a.p., bldz. 152).

Daar is een hoog verheven gebod, wiens grondslag rust op de wille des Koninks, van de wereld te gehoorzamen, zo verheven als de Zon, van het Hof, het welk een Myne is van geregtigheyd, gezegend, en vol van Gods stede-houderschap, zodanig met glans uytgegaan, namelyk:

Het handvatzel van verheventheyd, en van de raatsheerschap de uytgelezenste in aangenaamheyd, een welvaart-zoeker van het Hof, waar naar toe alle menschen haar toevlugt nemen, een verzekerde

1) Misschien: „G'. Hooft, Comp ${ }^{1 \text { es }}$ clercq".

2) Uit Havart, Cormandel, II, bldz. 152, v. In Contractboek - Zeeland IV, komt een kort uittreksel voor. - Over den datum vgl. men het slot.

3) Vgl. hiervóór, bldz. 513, noot 3). 